\title{
Medisinsk skjønn kan redusere sosiale helseforskjeller
}

\author{
Helsetjenesten kan bidra til å forsterke sosial ulikhet i helse. Å hindre dette bør ikke gjøres gjennom flere \\ lover, men ved å utvikle legenes medisinske skjønn.
}

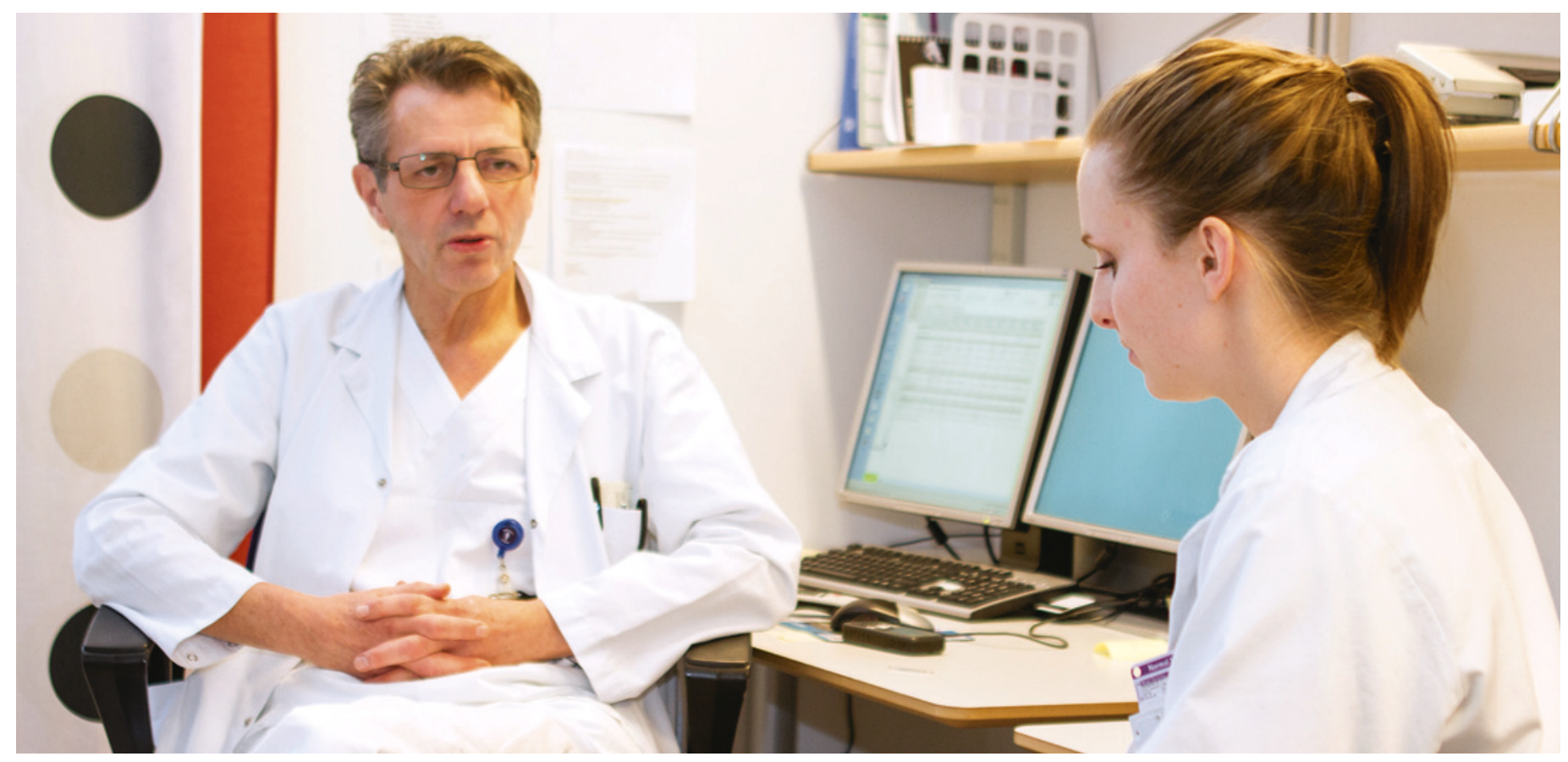

Illustrasjonsfoto: Ole Kristian Losvik

Lovfesting av menneskerettigheter er et virkemiddel for å sikre alle mennesker like muligheter i et samfunn. Tanken er at lovfesting vil øke sannsynligheten for at den enkeltes rettigheter blir ivaretatt. Vil flere eller mer detaljerte lover bidra til å øke sannsynligheten for likebehandling i helsetjenesten? Dette spørsmålet diskuterer Bærøe \& Bringedal i en ny bok (1).

Et visst utdanningsnivå og god helse er også viktige forutsetninger for borgernes aktive deltakelse i et samfunn. Å sikre lik rett til utdanning og helse er nødvendig for å sikre like muligheter. I 2014 har man diskutert om flere sosiale rettigheter bør grunnlovsfestes. Stortinget vedtok å inkludere utdanning, men ikke helse (2).

Sosial ulikhet $i$ helse observeres $i$ alle samfunn. Ulikheten har mange årsaker, og de viktigste skyldes ikke ulik tilgang til helsetjenester. Men helsetjenesten kan bidra til å opprettholde, forsterke eller redusere ulikheten. Derfor er det et politisk mål

å sikre lik tilgang uavhengig av sosioøkonomisk status.

\section{Hva betyr likebehandling?}

En generell rett til helsetjeneste kan bidra til å sikre lik tilgang til helsetjenester. Men vil mer detaljert lovregulering bidra positivt? Man kunne f.eks. tenke seg en lov som gir behandlingsprioritet til sosioøkonomisk vanskeligstilte. Dette er vanskelig å forsvare (1).

Hva innebærer likebehandling i helsetjenesten? Det er ikke behandlingen som skal være lik, men muligheten for å realisere samme helsemessige resultat. Dette krever ulikebehandling - basert på skjønnsmessig vurdering av hva som må til for at den enkelte pasienten skal kunne nyttiggjøre seg behandlingen. Legen tar hensyn til de individuelle faktorene som påvirker behandlingsresultat, ikke bare «rent medisinske» faktorer, men også forhold som pasientens alder, kjønn og sosioøkonomiske faktorer.
Slike forhold er ikke mulig å spesifisere i loven. Skjønnsutøvelse er en nødvendig betingelse for at individuelle faktorer blir tatt hensyn til. A forhindre at helsetjenesten bidrar til å forsterke sosial ulikhet bør ikke gjøres gjennom flere lover, men ved kultivering av legenes medisinske skjønn.

\section{Berit Bringedal}

berit.bringedal@legeforeningen.no

Berit Bringedal er dr.polit. og seniorforsker i Legeforskningsinstituttet.

Litteratur

1. Bærøe K, Bringedal B. Professionalism, discretion and juridification: Social inequality in health and social citizenship. I: Aasen H, Gloppen S, Magnussen AM et al. Juridification and social citizenship in the welfare state. London: Edward Elgar Publishing, 2014.

2. Tverberg A. Grunnloven og velferdsstatens menneskerettigheter. http://lovdata.no/artikkel/ grunnloven_og_velferdsstatens_menneskerettigh eter/1440 (20.10.2014). 